Journal of Balkumari College

ISSN : 2467-9321 Website: http://www.nepjol.info/index.php/jbkc

Volume : 9, Issue : 1, June 2020, Page No.: 71-83

\title{
Influence of Children on Parental Purchase During Shopping in Supermarket
}

\author{
Ganga Prasad Sapkota* \\ Sarad Chandra Kafle
}

\begin{abstract}
Due to changing patterns of Nepalese life style and urbanization, parents are providing more value to their children and they are investing for children's tour, entertainment and for shopping that's why number of parental visit is found in park, shopping mall, zoo etc. Supermarket shopping has no longer history in Chitwan. Bhatbhateni supermarket is one of the famous and popular supermarket in this locality. This is famous among the purchaser because of facilities it has and varieties of goods available in the mall. Lift facility and ice-cream outside the mall attracting children towards this shopping mall. This study is focused on the purchasing behavior parents due to children's demand who are visiting in Bhatbhateni supermarket(BBSM). Objectives of this study was to determine whether there is any influence of children on shopping behavior of their parents or not, if has influence what was the proportion of such parents, what are the major demands of children at BBSM. To fulfil the objectives of this study using purposive sampling of 60 customers attending in Bhatbhateni supermarket, Bharatpur is selected, the study is done on the basis of their response. Using structured questionnaire. The research design used is descriptive research design. Using SPSS data was compiled and analyzed. Simple frequency and percentage analysis has been carried to explain outputs, also chi-square test and Fisher's exact test has been carried to find out the association between variables under study. Outcomes of this study shows that children's influence is their in parental purchase during shopping at BBSM. Parents, businessman and investors of BBSM are considering major beneficiaries of this study.
\end{abstract}

Key Words: Chi-square test, Fisher's Exact test, Purchasing behavior, Supermarket shopping

\section{INTRODUCTION}

Consumer behavior is defined as the differential behavior of the people over time as they acquire process and use information from various sources and settings in purchasing, consuming and communicating brands and cluster of products. A human being by nature, is very complex. It is very difficult to understand human behavior (Reynolds \& Wells, 2000). It is the human brain, which directs all the activities of a human being. Therefore, even though consumer behavior cannot be precisely quantified and marketing decisions have to be based on probabilities, it is much better to know this behavior and then take decisions rather than taking them without any study. The initial thrust of consumer research was from a managerial perspective, marketers were interested in knowing how people received, stored and used consumption related information, so that tailor made marketing strategies could be designed. They believed that consumer behavior, if predicted could be influenced as well (Schiffrnan \& Kanuk, 2000). In earlier days, this approach was known by Positivism. However, slowly the marketers realized that this is a tough task. Predicting consumer behavior was highly impossible and it is then that emphasis was laid on understanding human behavior. This approach was called as interpretive approach. These two approaches of positivism and interpretivism believe that both predicting and understanding together give a richer and robust portrait of consumer behavior than either approach used alone.

Purchasing decision-making is a complex and multi-stage process, which is undertaken not only by the purchaser himself/herself, but under the impact of other parties as well. Family decision-making constitutes an important area to explore. Marketing practitioners as well as scholars studying the area frequently highlight this importance.

Although the influence of children in the family decision making process has been accepted as a force which neither academics nor practitioners can ignore, Consumer socialization in families is a two-way process,

* Corresponding author: gangasapkota3067@gmail.com 
that is, the kids also act as a medium to socialize the parents by influencing the family purchase decisions.

Children sometimes either purchase a product themselves or select the product before the parents purchase it. For other products, such as ones, which are used by the entire family unit, they may influence purchases made by the parents. There are some products where children get directly influenced or pester powered by overtly specifying their preferences and voicing them aloud. For other products, parents' buying patterns are affected by prior knowledge of the tastes and preferences of their children. This passive dictation of choice is prevalent for a wide variety of daily consumed product items as well as products for household consumption. Also, decision making in households is seen to change with the mere presence of children. It is also observed that children are socialized by their parents to act as rational consumers. After years of direct or indirect observation of parental behavior in the marketplace, they gradually acquire relevant consumer skills from their parents.

The amount of influence exerted by children varies by product category and stage of the decision making process. Some products are instrumental in initiating a purchase, while for others; they make the final selections themselves. Family, peers and media are key socializing agents for children wherein family-specific characteristics such as parental style, family's Sex Role Orientation (SRO), and patterns of communication play key roles. The Indian families have become more modern in SRO, such that the decision-making has become more egalitarian (Chadha, 1995; Dhobal, 1999). Compared to this, the West is experiencing an increase in the number of single parent or female-headed households (Ahuja and Stinson, 1993; Mangleburg et al., 1999). Such a shift in family composition and structure has a bearing on the strength in the role that children are expected to play as buyers in the family.

\section{STATEMENT OF THE PROBLEM}

Even though a great number of studies and research projects in the family decision making area have been conducted, there are several reasons why there is a need to revise and update the previous and current studies in this area.

First, the previous and current studies on the family decision-making process were conducted mostly in developed countries such as the USA and those in Europe. Although many phases could be generalized in other countries, it might not be applicable and suitable to families from other countries such as Indonesia where the culture, norms, and characteristics of the family are different from those in Western countries.

Secondly, there are many studies concerning children's influence in family decision making on buying luxury goods or where to go for vacation. However, few studies refer to children's influence in food buying and consumption. Especially the topics of what kind of foods are most influenced by children and how the influence occurs during the food decision-making process.

Finally, the previous and current empirical works have stated that children have an influence in the family, however few mention the measurement of influence and the role of children in the family (either as the primary, co-decision maker, influencer, or having no influence at all).

Based on the matters mentioned above that there is a need for further research about children's influence in other countries in specific areas such as food buying and food consumption where children have the most influence and in specific measurements in order to determine the children's influence. Therefore, through this study of children's influence in Jakarta, Indonesia, the topic can be better clarified.

\section{OBJECTIVES OF THE STUDY}

The main aim of the study is to examine the behavior of children in Chitwan, in terms of their participation and influence in family decision-making during Supermarket shopping.

- To study the role of kids in purchasing decision in family.

- To study the factors which influence children's decision in selecting a product.

- To study the influence of kids in purchasing decision by product category. 


\section{SIGNIFICANCE OF THE STUDY}

This study centered to examine the behavior of children in Chitwan, in terms of their participation and influence in family decision-making during Supermarket shopping, so stakeholders of this study are parents of the children who used to visit Bhatbhateni supermarket, Bharatpur, Chitwan, all the staffs of this supermarket, proprietor of this supermarket. Outcomes of this research are useful to all of these stakeholders.

\section{LIMITATION OF THE STUDY}

This study is limited to the response of parents coming with their children for shopping at Bhatbhateni supermarket, Bharatpur, the respondents are selected purposively. Among all the visitors at Bhatbhateni supermarket, Bharatpur, researcher selected some visitors coming with children assuming the sample visitors will represent all the visitors coming with children. Hence, the study will represent the customers of Bhatbhateni supermarket, Bharatpur Chitwan. The present study is not free form limitations. The limitations of the study are presented as follows:

- The study only covers the purchasing practices of the customers of Bhatbhateni supermarket, Bharatpur.

- The study is based on the primary data. Structured questionnaire is used for collecting the primary data. Therefore, responses must be filled in the questionnaire based on the alternatives developed by researcher.

- The accuracy of this study is depending upon the true response of the respondents.

The study is depending on information gathered from selected manufacturing enterprises and the researcher assumes that the sample visitors selected using purposive sampling.

\section{METHODS AND MATERIALS}

The population for the study is comprised of all the customers attending in Bhatbhateni supermarket. Information provided by Bhatbhateni supermarket, in average 200 customers arriving daily in this supermarket. These customers of this supermarket are the population of the study.

This research is related with the parental influence from their children attending on supermarket especially attending in Bhatbhateni supermarket, Bharatpur, Chitwan district. As stated previously that the research is based on the primary data. Primary data collection based on the structured questionnaire which has been used to collect various data related to the objectives of the research work.

Once the data and information properly collected then the compilation, tabulation, presentation, analysis and interpretation will have been carried out.

\section{RESULT AND DISCUSSION}

After the collection of data, the researcher has compiled data in computer software using Microsoft Excel. Thus, gathered data is transformed into SPSS for analysis process. All the respondents got ready to answer with the researcher. Thus, the researcher got 60 respondents as sample respondents. After reliability test for the data required analysis are carried. The reliability test shows the Cronbach's Alfa as 0.734 , which implies the data is reliable for analysis purpose.

Age of the parents has been categorized into five groups for the actual information with the different taste within their response. Not only the age factor but also gender of the children and the relation of the parents with the children and the occupation of the parents play an important role to determine the shopping habit of the parents as well as the children.30-40 age group parents are the most regular visitors of the Bhat-Bhateni Superstore. The percentage of them is the highest one. The second common visitors are from the age group of 40-50. The study presents the actual information about the role of the researcher to present the actual data on the basis of the real visitors who visit Bhat-Bhateni Supermarket with their children. Analysis shows that the children feel comfortable with their father or mother to visit the superstore because they may get better opportunity to fulfill their demands with their parents more than with their other relatives. Another determining factor regarding the shopping habit of the children depends upon the income level of their parents and the type of the job they do. As they earn so they learn to visit the store. The more the parents earn, the more they do shopping with the children.

To study different demand of children during supermarket shopping different questions are asked, Customers 
of Bhat-Bhateni responded in the following way. Their response is presented through the given table on the basis of the primary data collection technique of the researcher. As the research has been taken place, it has been clarified that the reply of the attendants goes as they are influenced by the habit of the children in the given way.

Table 1: Demand Analysis of children

\begin{tabular}{|l|c|c|}
\hline Particulars & Frequency & Percentage \\
\hline Who plans for shopping? & 51 & 85 \\
\hline Mother & 7 & 11.67 \\
\hline Father & 1 & 1.67 \\
\hline Children & 1 & 1.67 \\
\hline Other Persons & 38 & 63.33 \\
\hline Who decides for shopping? & 21 & 35.00 \\
\hline Mother & & 0.00 \\
\hline Father & 1 & 1.67 \\
\hline Children & $\mathbf{6 0}$ & $\mathbf{1 0 0}$ \\
\hline Other Persons & & 68.33 \\
\hline Total & 41 & 26.67 \\
\hline Are all demands fulfilled? & 16 & 5.00 \\
\hline Always (yes, every time or every day) & 3 & 76.67 \\
\hline Often (yes, but only about 3 times a week) & & 3.33 \\
\hline Sometimes (yes, but only once a week) & 46 & 16.67 \\
\hline Are Children happy for shopping? & 2 & 3.33 \\
\hline Yes & 10 & $\mathbf{1 0 0}$ \\
\hline No & 2 & $\mathbf{6 0}$ \\
\hline Sometime & & \\
\hline Don't Know & & \\
\hline Total & & \\
\hline Source & & \\
\hline
\end{tabular}

\section{Source: Field Survey 2019}

Table 1 demonstrates that greater power relies on female when the plan and decision of shopping come in front of the family. Mother plans for shopping the most in the family which is $85 \%$ as given in the figure. It shows the craze of her in the family for shopping. As the matter of decision comes for shopping, father also plays an important role on contrary to the plan of shopping. In more than $35 \%$ families, decision of shopping stays with the father with is almost two times less than of mother with $63 \%$ as shown in Table 4.

The given information shows that the demand of $68 \%$ families is fulfilled regularly as they go for shopping in Bhat-Bhateni supermarket in regular basis. The remaining percentage of families also shows that there remain a number of people who do not become able to fulfill their demands as they go for shopping. As the shopping goes pre-planned in the family, most of the children become excited and happy for shopping. It is shown in the figure that $76 \%$ children in all families become happy for shopping. For the remaining, it can be seen that they still want to do more shopping as they want more and more.

Following pie chart shows pattern of reasons to come in Bhat-Bhateni Supermarket. 
Figure 1: Reasons to Visit in Bhat-Bhateni

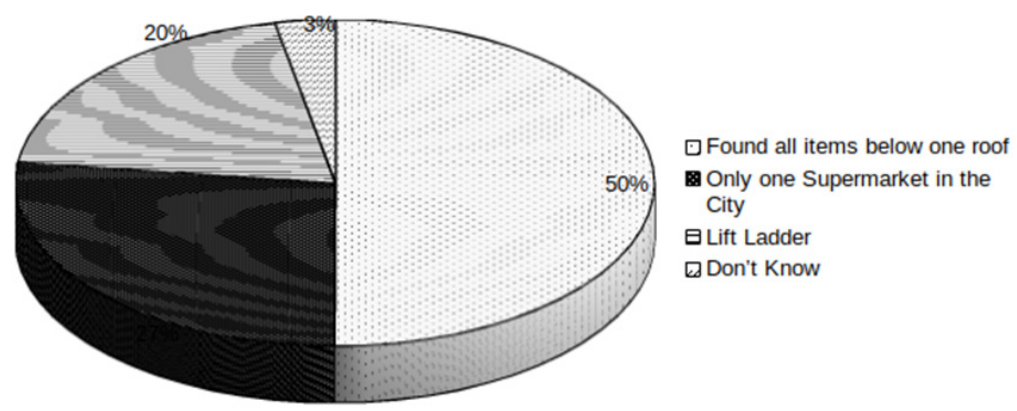

Source: Field Survey 2019

Figure 1 trying to clear that the highest portion of the children with their parents chooses to visit BhatBhateni because they find all of the purchasing items under one roof. This very reason encourages half of the people to visit this supermarket out of the 60 respondents according to the research. Some visitors prefer visiting it for the reason that it is the only one supermarket in the city and some people choose to visit it because of the lift ladder installed in it with $27 \%$ and $20 \%$ respectively. The least number of people visit it without any specific reason. They just do it. There is no base for them to visit the supermarket. They just see it from outside and prepare their mind to enter inside and may so some shopping or may come outside just by observing it.

\section{Figure 2: Source of Information about Goods for Shopping}

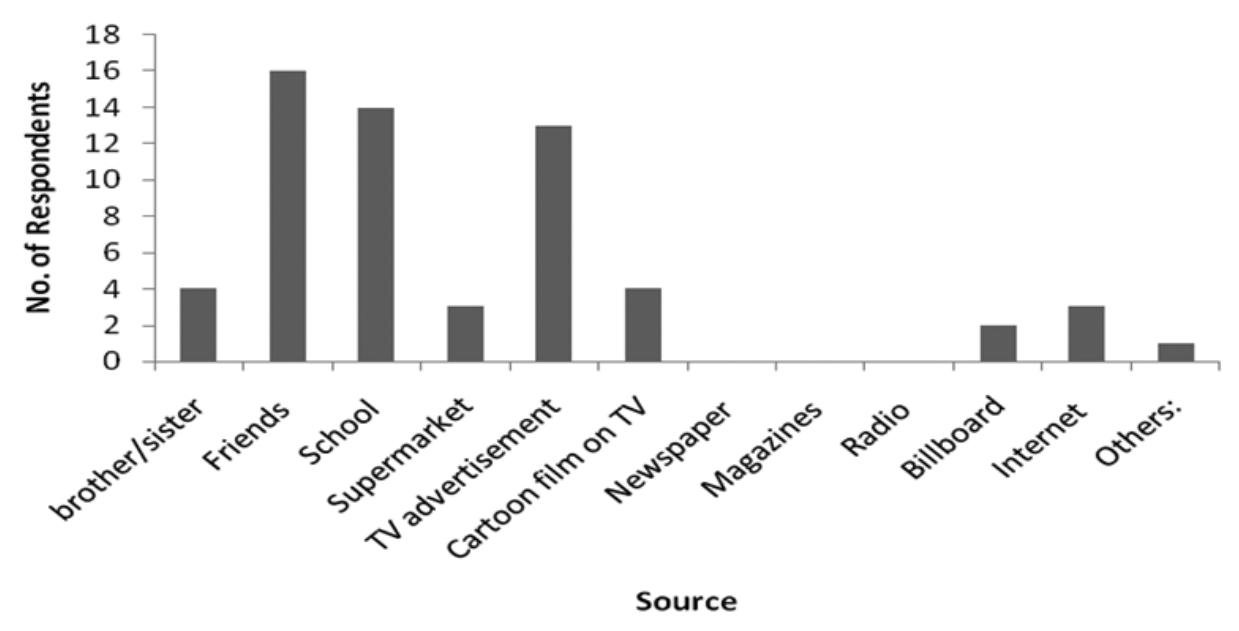

\section{Source: Field Survey 2019}

As it is given in the above-mentioned bar diagram, children get knowledge about the goods for shopping through various sources. Out of the total number of respondents, almost 16 children get information about various things from their friends. Around 13 and 12 respondents got informed about the shopping goods from their school and TV advertisement respectively as per the diagram. The role of brother/sister and cartoon film on TV seems to be the same as it is shown in the diagram. The contribution of newspaper and magazines seems to be of nothing as it is given in the statistical figure. Some respondents got informed through internet too so that it can't be neglected as it is also the main source of information.

Following table shows behavior of children during shopping at Bhat-Bhateni Supermarket Bharatpur. To know how often children come with their parent, for what purpose they were mainly coming, how often they used to come to this supermarket, questions were raised their responses are shown in Table 2 
Table 2: Shopping Behavior of Respondents

\begin{tabular}{|l|c|c|}
\hline Questions & Frequency & Percentage \\
\hline Why children come to BSM? & & \\
\hline Found all items below one roof & 30 & 50.00 \\
\hline Only one supermarket in the city & 16 & 26.67 \\
\hline Lift ladder & 12 & 20.00 \\
\hline Don't Know & 2 & 3.33 \\
\hline Total & $\mathbf{6 0}$ & $\mathbf{1 0 0}$ \\
\hline How often do they come here? & 4 & \\
\hline Every day & 13 & 2.67 \\
\hline Two or Three times a week & 35 & 58.67 \\
\hline Once a week & 8 & 13.33 \\
\hline Once a month or less & 0 & 0.00 \\
\hline Random & $\mathbf{6 0}$ & $\mathbf{1 0 0}$ \\
\hline Total & & 36.67 \\
\hline How often do parents come with children? & 22 & 61.67 \\
\hline Always & 37 & 1.67 \\
\hline Sometimes & 1 & $\mathbf{1 0 0}$ \\
\hline Never & $\mathbf{6 0}$ & \\
\hline Total & & 83.33 \\
\hline Do parents come here due to children approach? & 50 & 16.67 \\
\hline Yes & $\mathbf{6 0}$ & $\mathbf{1 0 0}$ \\
\hline No & & \\
\hline Total & & \\
\hline Source & & \\
\hline
\end{tabular}

\section{Source: Field Survey 2019}

As it has already been described, the children also choose to go to Bhat-Bhateni because they find all of the items to their interest under one roof. Around 59\% people choose to go to Bhat-Bhateni every week. The advancement may attract them to visit and buy something over there. The children who go two or three times a week in Bhat-Bhateni also stand with about $22 \%$ according to the given data. Most of the parents visit Bhat-Bhateni because they want to show their children something over there. As they take their children to Bhat-Bhatenni, hey may ask for some other items to buy which are not necessary. So, most of the parents prefer taking their children to Bhat-Bhateni only occasionally. But, on contrary to the parents' planning, they become forced to visit BhatBhateni because of their children. Almost $84 \%$ parents go there because of their children who demand with them to go there.

To know the shopping item mostly demanded by the children during supermarket shopping, question is raised 'what are the items for children you bought?'. The responses are tabulated in the Table 3. Rank is used to determine most favorable item and rarely demanded items during supermarket shopping. The demanded items by children and thus purchased by parents have been categorized in to three types, namely food, clothes and playing items. Rank for overall items and within the product category is calculated using Microsoft Excel with the formula RANK. The rank calculation method is "provide 1 rank for the product which has highest frequency of purchases and accordingly provide $2^{\text {nd }}, 3^{\text {rd }}, 4^{\text {th }}$ and so on ranks thus the product having rank 1 is the highest purchased item or the most popular product. 
Table 3: Most Favorable Items of Children

\begin{tabular}{|c|c|c|c|c|}
\hline & & & & $\mathrm{n}=$ \\
\hline Category & Products & $\begin{array}{c}\text { Number of persons pur- } \\
\text { chases the item }\end{array}$ & Rank in total & Rank within Category \\
\hline & Soups & 1 & 18 & 18 \\
\hline & Juice & 2 & 16 & 7 \\
\hline & Snacks & 2 & 16 & 7 \\
\hline & Bread & 3 & 14 & 6 \\
\hline & Horlicks & 3 & 14 & 6 \\
\hline Food Items & Jam & 4 & 13 & 5 \\
\hline & Nuts & 9 & 8 & 4 \\
\hline & Noodles & 13 & 5 & 3 \\
\hline & Biscuits & 21 & 2 & 2 \\
\hline & Ice-cream & 21 & 2 & 2 \\
\hline & Chocolate & 27 & 1 & 1 \\
\hline & Jeans & 1 & 18 & 7 \\
\hline & Towel & 1 & 18 & 7 \\
\hline & Bags & 6 & 11 & 5 \\
\hline & Cap & 6 & 11 & 5 \\
\hline Clothes & School bag & 7 & 9 & 4 \\
\hline & T-shirt & 10 & 7 & 3 \\
\hline & Shoes & 11 & 6 & 2 \\
\hline & Pant & 19 & 4 & 1 \\
\hline & Gun & 1 & 18 & 2 \\
\hline & Helicopter & 1 & 18 & 2 \\
\hline Playing Items (toys) & Toys & 7 & 9 & 1 \\
\hline
\end{tabular}

\section{Source: Field Survey 2019}

Table 3 shows that chocolate is most preferred items among the purchased item by the children visiting with their parent at Bhat-Bhateni Supermarket, Bharatpur. Among the 60 children 27 have demanded Chocolates and their parent have purchased the item. The second demanded products were Biscuit and Ice Cream, the third demanded item was the cloth Pant. Among food items Chocolates, ice cream and biscuit, noodles are respectively purchased by maximum parents for their children. Among the Cloth items Pant, Shoes and T-shirts are top three demanded items by children and purchased by their parents.

To find out whether parents come due to the approach of their children a question is asked to the parents "did you come here due to children's approach?" their responses recorded shown in following pie chart.

Figure 3: Parent's arrival at BBSM due to their children's approach

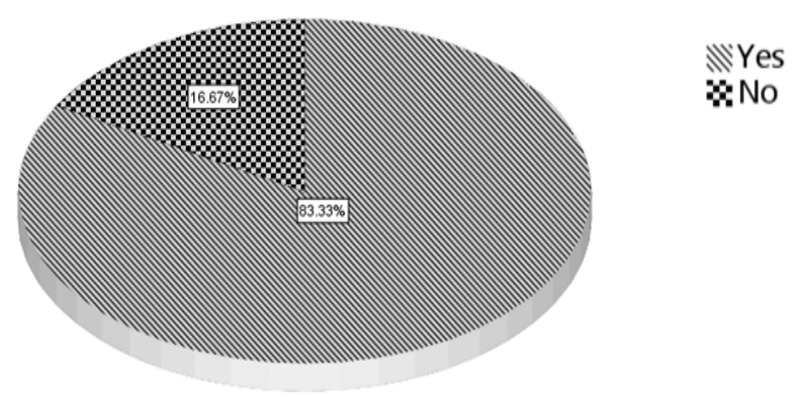


Above pie chart shows that parents are being influenced from their children for supermarket supping because more than three fourth respondents told that they come at Bhat-Bhateni Supermarket due to the approach of their children.

Children force to purchase their parents while shopping where they are together with their parents. Some children force to buy the entire items seen in the market without knowing about the product. So they may show different activities during supermarket shopping. Here are some tables where researcher trying to get information on children's activities during supermarket shopping.

After they get their demanded goods they may be happy or may demand additional item, some parent fulfill children's demand at first and then others, how parents are responding for children's demand, to know answers of these questions researcher has asked related question on these matter and the responses are tabulated in Table 4.

Table 4: Children's Activities in Supermarket

\begin{tabular}{|l|c|c|}
\hline \multicolumn{1}{|c|}{ Questions } & Frequency & Percentage \\
\hline Enjoy for shopping & & \\
\hline Yes & 41 & 68.33 \\
\hline No & 4 & 6.67 \\
\hline Sometime & 13 & 21.67 \\
\hline Don't know & 2 & 3.33 \\
\hline Total & $\mathbf{6 0}$ & $\mathbf{1 0 0}$ \\
\hline Whose demand is fulfilled first? & 37 & 61.67 \\
\hline Children's & 16 & 26.67 \\
\hline Families & 6 & 10 \\
\hline Own & 1 & 1.67 \\
\hline First available item first & $\mathbf{6 0}$ & $\mathbf{1 0 0}$ \\
\hline Total & & \\
\hline What items usually are included in shopping? & 46 & 76.67 \\
\hline Food & 8 & 13.33 \\
\hline Clothes & 11 & 18.33 \\
\hline Playing items & $\mathbf{6 0}$ & $\mathbf{1 0 0}$ \\
\hline Total & & \\
\hline Children's demands on today's shopping & 37 & 61.67 \\
\hline Food & 18 & 30 \\
\hline Clothes & 8 & 13.33 \\
\hline Playing items & $\mathbf{6 0}$ & 0 \\
\hline Other & $\mathbf{1 0 0}$ \\
\hline Total & & \\
\hline Source Fied Survy & & \\
\hline
\end{tabular}

\section{Source: Field Survey 2019}

The given table presents the clear view of the visitors' happiness after visiting Bhat-Bhateni. Almost $69 \%$ people became happy and enjoy after visiting there. One fifth of the people only become happy sometimes as they visit Bhat-Bhateni. After visiting this shopping market, it seems that parents only go there to fulfill their children's demand at first. Around $62 \%$ children become happy after visiting it. The main purpose of the customers becomes to buy different types of food items while shopping in Bhat-Bhateni supermarket. Nearly $77 \%$ people visit it for busying food items. The children also insist on buying some food items as they enter inside the market. The given tabular data also shows that nearly $62 \%$ people demanded for different types of food items on that day's shopping. 
Figure 4: Ways of Availing for parents by their Children

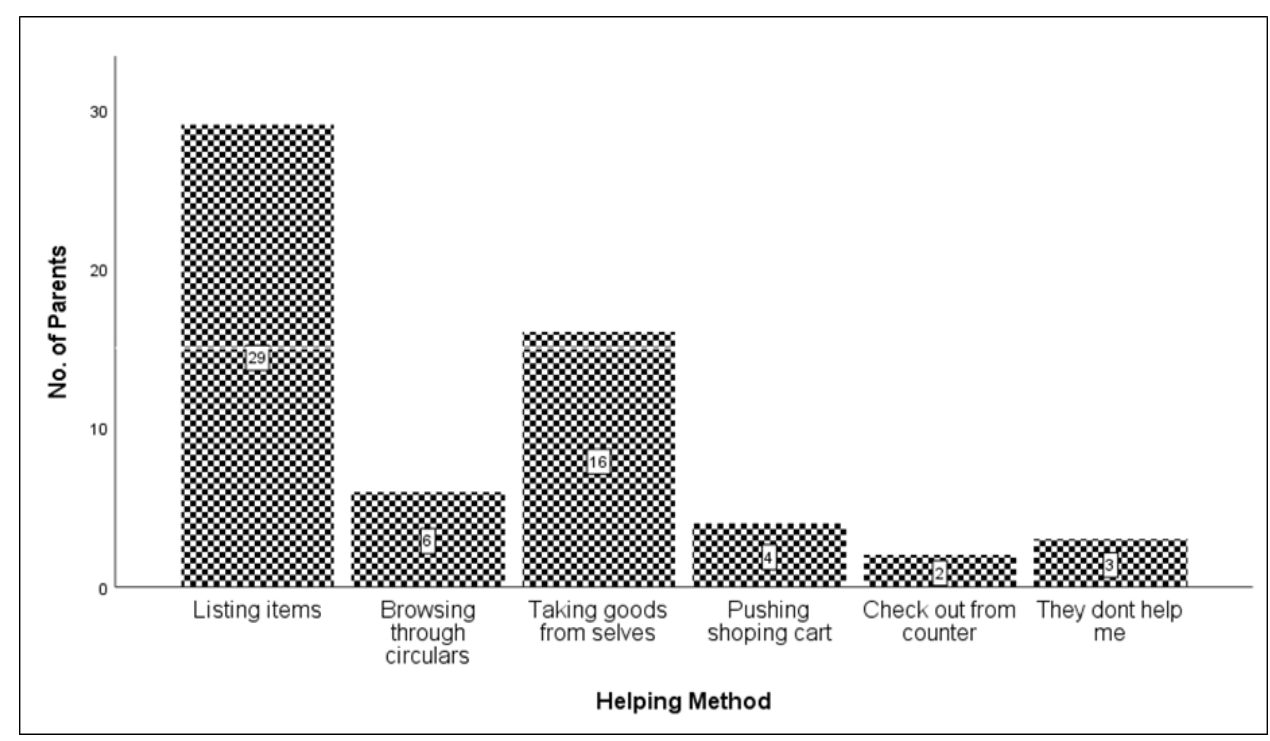

\section{Source: Field Survey 2019}

Bar diagram in figure 4 shows that most of the children always help their parents while by some means. As they enter inside the market, they give some suggestions to their parents regarding the way of buying the stuff. Most of the children help their parent to list their shopping list, the frequency of parent who told that their children help them to list shopping item is 29 which almost 50\%. Children help their parent during shopping in Bhat-Bhateni supermarket by mean of browsing through circular, pushing shopping cart, check out good from counter, such helping method have nearly same frequency. Few numbers of parents ( 3 parents) told that their children do not help them at any mean.

Table 5: Food Purchasing Habit of Children

\begin{tabular}{|l|c|c|}
\hline Particulars & Frequency & Percentage \\
\hline How often do you buy food for children? & & \\
\hline Always & 37 & 61.67 \\
\hline Often & 16 & 26.67 \\
\hline Sometimes & 6 & 10 \\
\hline Seldom & 0 & 0 \\
\hline Never & 0 & 0 \\
\hline Never & 1 & 1.67 \\
\hline Don't know & 0 & 0 \\
\hline Total & $\mathbf{6 0}$ & $\mathbf{1 0 0}$ \\
\hline How often do Children demand for food? & & \\
\hline Always & 45 & 75 \\
\hline Often & 9 & 15 \\
\hline Sometimes & 5 & 8.33 \\
\hline Seldom & 0 & 0 \\
\hline Never & 1 & 1.67 \\
\hline Never & 0 & 0 \\
\hline Don't know & 0 & 0 \\
\hline Total & $\mathbf{6 0}$ & $\mathbf{1 0 0}$ \\
\hline
\end{tabular}




\begin{tabular}{|l|c|c|}
\hline Food they want to buy & & \\
\hline Fruits & 19 & 31.67 \\
\hline Vegetables & 4 & 6.67 \\
\hline Cereal & 2 & 3.33 \\
\hline Breads & 19 & 31.67 \\
\hline Jam & 5 & 8.33 \\
\hline Milk Juice & 4 & 6.67 \\
\hline Meat or fish, Egg & 1 & 1.67 \\
\hline Noodle & 6 & 10 \\
\hline Total & $\mathbf{6 0}$ & $\mathbf{1 0 0}$ \\
\hline
\end{tabular}

Source: Field Survey 2019

As the parents take their children inside the store, they want to buy something there for the children to eat. Nearly $62 \%$ parents but food items for their children as they can't see them unhappy while entering inside. $75 \%$ children always demand for food while doing shopping in the superstore. Both fruits and breads are liked by the children to buy while doing the shopping. The percentage is also the same. It seems clear that noodle is also the second liked food item.

Table 6: Clothes Demanding Habit of Children

\begin{tabular}{|l|c|c|}
\hline \multicolumn{1}{|c|}{ Particulars } & Frequency & Percentage \\
\hline How often do you buy clothes? & & \\
\hline Always & $\mathbf{3 3}$ & $\mathbf{5 5}$ \\
\hline Often & 15 & 25 \\
\hline Sometimes & 0 & 16.67 \\
\hline Seldom & 2 & 3.33 \\
\hline Never & $\mathbf{6 0}$ & $\mathbf{1 0 0}$ \\
\hline Total & & \\
\hline How often do children ask to buy clothes? & 44 & 73.33 \\
\hline Always & 11 & 18.33 \\
\hline Often & 3 & 5 \\
\hline Sometimes & 1 & 1.67 \\
\hline Seldom & 1 & 1.67 \\
\hline Never & $\mathbf{6 0}$ & $\mathbf{1 0 0}$ \\
\hline Total & & 31.67 \\
\hline Which clothes are the most demanded? & 19 & 15 \\
\hline Shirt & 9 & 41.67 \\
\hline Pant & 25 & 11.67 \\
\hline Tea shirt & 7 & 0 \\
\hline Skirt & 0 & $\mathbf{1 0 0}$ \\
\hline Cap & $\mathbf{6 0}$ & \\
\hline Total & & \\
\hline Source & & \\
\hline
\end{tabular}

Source: Field Survey 2019

On the basis of the research, children demand with the parents to buy different types of fancy clothes on regular basis. 55\% customers of Bhat-Bhateni Supermarket buy clothes too as they enter inside it for shopping. $74 \%$ children demand to buy clothes with the parents as different types of clothes are provided there. T-shirt hasbeen 
most demanded by the children in Bhat-Bhateni regarding the matter of buying clothes. Shirt, pant, skirt are also chosen by the children as they come here for shopping. As T-shirt is common clothe for boys and girls, it may be more demanded cloth among the children. In addition to this shirt is also unisex cloth fit for both gender so it may be seen as second most demanded item in cloth category.

Table 7: Playing Items Demands of Children

\begin{tabular}{|l|c|c|}
\hline Particulars & Frequency & Percentage \\
\hline How often do you buy Playing Items? & & \\
\hline Always & 27 & 45 \\
\hline Often & 22 & 36.67 \\
\hline Sometimes & 9 & 15 \\
\hline Seldom & 1 & 1.67 \\
\hline Never & 1 & 1.67 \\
\hline Total & $\mathbf{6 0}$ & $\mathbf{1 0 0}$ \\
\hline How often do children ask to buy Playing items? & & \\
\hline Always & 43 & 71.67 \\
\hline Often & 9 & 15 \\
\hline Sometimes & 6 & 10 \\
\hline Seldom & 1 & 1.67 \\
\hline Never & 1 & 1.67 \\
\hline Total & $\mathbf{6 0}$ & $\mathbf{1 0 0}$ \\
\hline Which clothes are the most demanded? & & \\
\hline Gun, Weapons & 12 & 20 \\
\hline Bus, Train, Jeep etc. & 14 & 23.33 \\
\hline Toys & 25 & 41.67 \\
\hline Animals & 7 & 11.67 \\
\hline Dolls & 1 & 1.67 \\
\hline Cooking utensils & $\mathbf{6 0}$ & 1.67 \\
\hline Total & & $\mathbf{1 0 0}$ \\
\hline Source & 1 & \\
\hline
\end{tabular}

Source: Field Survey 2019

Out of the varieties of goods, different playing items are also kept there for all sorts of people. As the customers enter inside, playing items also attract the mind of the people. They get interested to buy them. The frequency of the customers buying the playing items is high as per the given data. As it is given in the data, $45 \%$ customers always buy something to play with while doing shopping in the Bhat-Bhateni supermarket. And the frequency of the customers buying playthings decreases. $41 \%$ of the customers choose to buy different types of toys as they enter inside Bhat-Bhateni. All of the statistical figures present the real mode of shopping in Bhat-Bhateni supermarket of the different types of people with their children. It is attracting the customers in many ways and people are also getting more excited to visit it for shopping purposes.

To study the association of different independent variables to dependent variable, demographic variables of parent and children are treated independent variable and their association is studied with the help of Chi-Square test and Likelihood Ratio test. The dependent variable treated here is shopping decision of parent which is measured in nominal scale. Chi-Square test is applicable to study the association between two variables if at least 50 units are selected as sample units, both the variables under study are categorical variable measured in nominal scale. While applying Chi-Square test, if more than $20 \%$ cell frequencies are less than 5 then Chi-Square test is not fit for this case and we can apply Likelihood Ratio Test in the alternative Chi-Square. 
Table 8: Association between Parents' Gender with Shopping Decision

\begin{tabular}{|l|c|c|c|c|c|}
\hline \multirow{2}{*}{ Parent's Gender } & \multicolumn{2}{|c|}{ Shopping Decision } & Total & Chi-square & \multirow{2}{*}{ P-value } \\
\cline { 2 - 4 } & Mother & Father & & & \\
\hline Female & 20 & 6 & 26 & \multirow{2}{*}{3.177} & \multirow{2}{*}{0.075} \\
\hline Male & 18 & 15 & 33 & & \\
\hline Total & 38 & 21 & 59 & & \\
\hline
\end{tabular}

Source: Field Survey 2019

Above table shows truncated data after neglecting the other persons who decide for shopping in Bhat-Bhateni Supermarket. Above tables shows 59 total respondents because out of 60 one respondent was other than the father or mother of children who decide for shopping. It is to be cleared that no any person in the survey responded that children decide to go for shopping. Result from SPSS reveal that not a single cell has expected frequency less than 5, so Chi-square test is applicable. The Chi-square test statistics 3.177 with p-value 0.075 in 1 degree of freedom, this data indicates that $p$-value is greater than the level of significance $(\alpha=0.05)$ so there is no association between gender of parent and their shopping decision in Bhat-Bhateni Supermarket. Which implies that both father and mother are equally enjoying for shopping with children at Bhat-Bhateni Supermarket, Bharatpur, Chitwan.

To find out whether children have influence their parents for shopping items according to their wish test of association for two qualitative variables is carried however data shows more than $20 \%$ of the cells in the Bivariate table have expected frequencies less than five so Likelihood Ratio test is carried, summary for the test is presented in following table

Table 9: Likelihood Ratio Test for Associations

\begin{tabular}{|l|l|c|c|c|}
\hline \multicolumn{2}{|c|}{ Variables } & $\begin{array}{c}\text { Likelihood } \\
\text { Ratio }\end{array}$ & df & P-value \\
\hline Shopping due to children approach & $\begin{array}{l}\text { How often you ask child for food } \\
\text { while shopping }\end{array}$ & 16.68 & 3 & 0 \\
\hline Shopping due to children approach & $\begin{array}{l}\text { How often you ask child for } \\
\text { clothes while shopping }\end{array}$ & 17.88 & 4 & 0 \\
\hline Shopping due to children approach & $\begin{array}{l}\text { How often you ask child for } \\
\text { playing items while shopping }\end{array}$ & 17.01 & 4 & 0 \\
\hline
\end{tabular}

Source: Field Survey 2019

Above table shows that Children's shopping approach is related with parents shopping habit because in all case $p$-value is less than level of significance $(\alpha=0.05)$. Even though parent's shopping decision is not associated with gender of parent and the gender of their children it is related with the communication of parents with their children. If children ask for their children to buy food, clothes and playing item it is clearly seen that these factors are significantly associated with shopping decision of parent due to children approach. This implies that once children ask to buy certain products, in most of the case parent decide to buy the demanded good.

\section{CONCLUSION}

This research study willing to find out the influence of children for supermarket shopping. Data analysis shows almost all parents' and children's demographic characteristics are associated with shopping planning and shopping decision of parents. Also children has been influencing parents to visit Bhat-Bhateni Supermarket, and they had made them agree to purchase goods according as their demand which is justified by Likelihood Ratio Test for association between shopping approach of children with frequency of communication for food shopping, frequency of communication for clothes shopping and frequency of communication for playing items shopping. Together with development of urban culture people in town area have developed a culture to visit shopping centers, 
Zoo, new places and parks. Various research concluded that parents visit such place due to children's grumble and same result is found in this research.

\section{REFERENCES}

Ahuja, R. D., and Stinson, K. M. (1993). Female-Headed Single Parent Families: An Exploratory Study of Children's Influence in Family Decision Making. Advances in Consumer Research, 20, 469-474.

Atkin, C. K. (1978). Observation of Parent-Child Interaction in Supermarket Decision-Making. The Journal of Marketing, 4(42), 41-45.

Beatty, S. E., and Talpade, S. (1994). Adolescent Influence in Family Decision Making: A Replication with Extension. Journal of Consumer Research, 2(21), 332-341.

Berey, L. A., and Pollay, R. W. (1968). The Influencing Role of the Child in Family Decision making. Journal of Marketing Research, 1(5), 70-72.

Bokemeier, J., and Monroe, P. (1983). Continued Reliance on One Respondent in Family Decision-Making Studies: A Content Analysis. Journal of Marriage and the Family, 3(45), 645-652.

Calvert, S. L. (2008). Children as Consumers: Advertising and Marketing. The Future of Children, 1(18), 205-234.

Carlson, L., and Grossbart, S. (1988). Parental Style and Consumer Socialization of Children. The Journal of Consumer Research, 1(15), 77-94.

Carlson, L., Grossbart, S., and Walsh, A. (1990). Mothers' Communication Orientation and Consumer- Socialization Tendencies. Journal of Advertising, 3(19), 27-38. ISSN: 2306-9007 Ishaque\&Tufail (2014) Chen, Z., and Woolley, F. (2001). A Cournot-Nash Model of Family Decision Making. The Economic Journal, 474(11), 722-748.

Comprehension and Perception of Print Advertisements. Journal of Advertising, 2(27), 83-98.

Corfman, K. P., and Lehmann, D. R. (1987). Models of Cooperative Group Decision-Making and Relative Influence: An Experimental Investigation of Family Purchase Decisions. The Journal of Consumer Research, 1(14), 1-13.

Corfman, K. P., and Lehmann, D. R. (1993). The Importance of Others' Welfare in Evaluating Bargaining Outcomes. The Journal of Consumer Research, 1(20), 124-137.

Cowan, G., and Avants, S. K. (1988). Children's Influence Strategies: Structure, Sex Differences, and Bilateral Mother-Child Influence. Child Development, 5(59), 1303-1313.

Cox III, E. P. (1975). Family Purchase Decision Making and the Process of Adjustment. Journal of Marketing Research, 2(12), 189-195.

Darley, W. K., and Lim, J. S. (1986). Family Decision Making In Leisure-Time Activities: An Exploratory Investigation of the Impact of Locus of Control, Child Age Influence Factor and Parental Type on Perceived Child Influence. Advances in Consumer Research, 13, 370-374.

Ebster, C., Wagner, U., and Neumueller, D. (2009). Children's influences on in-store purchases. Journal of Retailing and Consumer Services, 16, 145-154.

EPP, A. M., and Price, L. L. (2008). Family Identity: A Framework of Identity Interplay in Consumption Practices. Journal of consumer research, 35 ,

Flurry, L. A., and Burns, A. C. (2005). Children's Influence on Purchases is Social Power Theory. Journal of Business Research, 5(58), 593-601.

Flurry, L. A., and Veeck, A. (2008). Children's Relative Influence in Family Decision Making in Urban China. Journal of Micromarketing, 00(000), 1-15.

Foxman, E. R, Tansuhaj, P. S., and Ekstrom, K. M. (1989). Family Members' Perceptions of Adolescents' Influence in Family Decision Making. The Journal of Consumer Research, 4(15), 482-491.

Gram, M. (2007). Children as Co-Decision Makers in the Family? The Case of Family Holidays. Young Consumers, $1(8), 19-28$.

Griffin, E. (1976). What's Fair to Children? The Policy Need for New Research on Children's Perceptions of Advertising Content. Journal of Advertising, 2(5), 14-18.

Grolnick, W. S., and Ryan, R. M. (1989). Parent Styles Associated With Children's Self-Regulation and Competence in School. Journal of Educational Psychology, 2(81), 143-154.

Guneri, B., Yurt, O., Kaplan, M. D., and Delen, M. (2009). The Influence of Children on Family

Harris Interactive, (2003). Trends and Tudes. 8(2), 1-5. 